\title{
The Influence of Green marketing, Syariah Compliance, Customer's Environmental Awareness and Customer's Satisfaction towards Muslim Consumer Purchasing Behaviour in Kedah
} *YATY SULAIMAN ${ }^{1}$, NUR AINA MOHD JAMIL ${ }^{1}$,
ABDUL RAHIM OTHMAN ${ }^{1}$, RUSNIFAEZAH MUSA

${ }^{1}$ School of Business Management, College of Business, Universiti Utara Malaysia, Kedah, MALAYSIA

\begin{abstract}
Day to day Muslims and non-Muslims customers are seeking for clean products and services which follows Islamic Shariah compliance principles. The purpose of this study is to identify the influencing factors of green marketing, Shariah compliance, customer's environmental awareness and customer's satisfaction towards Muslim purchasing behaviour at Kedah, Malaysia. A random sampling technique used to collect the respondents in Kedah, Malaysia also with quantitative approach through structured questionnaires developed from previous research. A total of 403 online survey questionnaires were distributed through Whatsapp application and Facebook pages. Data analysis were done with SPSS 25.0. Methodologies such as Pearson Correlation and Multiple Regression Analysis were used to analyse data collected. Findings revealed that consumer purchasing behaviour has a positive and significant relationship with green marketing, Shariah compliance, customer's awareness and customer's satisfaction. Finally, this study is concluded with discussion, limitations of the study and some suggestions for future researches.
\end{abstract}

Keywords: - Customer purchasing behaviour, Green marketing, Shariah compliance, Customer's awareness, Customer's satisfaction

Received: December 3, 2019. Revised: March 31, 2020. Accepted: April 13, 2020. Published: April 20, 2020.

\section{Introduction}

A Muslim consumer are only allowed to seek for a products and services which follows Islamic principles as a responsible Muslim. Sustainability is a supreme business development and transformation in this current business world, also important to focus on how to develop business to meet customers marketing needs, (Punitha, Aziz\& Rahman, 2016) [1]. PEW Forum of Religion and Personal Life, (2011) [2] reported that there are $25 \%$ of Muslims from world's population has increased the demand for Muslim products and services in current market. The increase of demand for Muslim products and services, may influence tourism industry for Muslimfriendly products (Omar, Islam\& Adaha, 2013) [3]. There were 25.7 million of international Muslim tourist arrival to Malaysia in 2017 compared to 26.8 million in
2016 (Tourism Malaysia, 2016) [4] and contributed $13.3 \%$ of gross domestic product (GDP) for the year 2018, (World Travel and Tourism Council, 2019) [5].

According to Forbes, (2018) [6], 87\% Americans are willing to purchase environmentally friendly products and services meanwhile $88 \%$ of these people has concerns on environmental issues support to loyal to these types of business. Green marketing is a process of selling and offering products or services with environmental benefits helping firms and businesses not only to market their products or services but also to increase consumers' awareness towards environment. Gitobu \& Njoroge, (2014) [7] stated that green practice is a different and a new trend in corporate social responsibility (CSR) of these companies. Research by Fernández-Alles\& 
Cuadrado-Marqués, (2012) [8] says that hotel industries from all over the world has started to concentrate on the environment in their day to day business operations for the past two decades. With this statistic, is it a great opportunity for hotel industries to implement green marketing and engage in Muslim related products and services to support environmental concerns. For this, the number of green hotels that are Shariah compliant should be increased and developed to attract more Muslim tourists and help them to fulfil their religious needs as a good Muslim. These types of hotels are not only focusing on focus in foods and beverages, but also in hotel facilities, operations, marketing, financial and human resource including as design, accessories, operation and other work-related activities based on Shariah principles. Makhdoomi and Nazir, (2016) [9] has said that 'green products' with less toxic, biodegradable, renewable, recyclable and energy efficient has a positive effect to the environment but depends on the beliefs and concerns of the consumer whether or not to purchase them. As shaped by Muslim religious beliefs it is a need for the Muslim consumers to go for halal foods, beverages and services according to Syariah principles.

Awareness regarding religious rules has increase the demand for product and service with Shariah compliance, nevertheless Department of Islamic Advancement Malaysia (JAKIM), 2012, [10] reported that there is no specific legal guideline to represent the hotel as per Shariah compliant even while obtaining halal certification. Additionally, Shaharuddin et al., (2018) [11] says that there is no a proper knowledge on Shariah Complaint Hotel (SCH) implementation in Malaysia even though consumers for Halal market in tourism industry are increasing. They have also added that knowledge about the concept of SCH in Malaysia is still at its infancy which might lead to misleading and confusions to nonMuslims on their perception of SCH. Most of the hotels in Malaysia are owned by nonMuslim and research by Othman, (2015) [12] says that these hotels are mostly conventional type and only few has claimed as $\mathrm{SCH}$ by the owners themselves. As the result, this can make the development of Shariah compliance hotels concept in Malaysia slower (Ahmat et al., 2015) [13]. However, Azizah et al., (2017)
[14], founds that there is a high demand in the global for Islamic services which leads to the rapid growth for Islamic tourism. Therefore, hotels should implement and apply Islamic values according to Shariah compliance in their operations to meet the demand for Islamic services and attract more on nonMuslims tourists to Malaysia.

\section{Literature Review}

\subsection{Halal Hotels in Malaysia}

Halal Travel and facilities is being one of the fastest growing demand in today's travel industry. Most numbers of hotels in Malaysia are practicing conventional hotel services, reasoning to the significance of the international tourism market. Malaysia is the first of the two countries to have a halal tourist industry (Idris \& Abdul Wahab, 2015) [15] and to secure and ensure this the Malaysian government has established the national accreditation body, JAKIM, to determine whether these hotels meets halal requirements (Samori \& Rahman, 2015) [16]. There were 102 hotels in Malaysia have been accepted as halal by JAKIM (Westeastinstitute, 2018) [17] JAKIM, SIRIM and HDC are three institutions identified as the most important parties to recognized bodies in pursuing the halal efforts. Hotels should encounter halal issue seriously as offenders could be punished under existing laws by these entities. Sahida et al. (2011) [18] has done a study on halal hospitality in Kuala Lumpur, Malaysia, and found that the reason for providing halal service is to cater to the needs of Muslim travellers that otherwise they may have difficulty to find accommodation that suits their lifestyle. Ahmad et al.(2012) [19] has provided an example of De Palma Hotel in Malaysia where it is a better pioneer Shariah Compliant hotel in the Asian region, yet only focusing tangible aspects, although the management of the De Palma Hotel 46 Group realises that the entire management of hospitality must be halal, adopting a Muslim personality'.

\subsection{Consumer Purchasing Behaviour}

Consumer purchasing behaviour is their final decision and buying behaviour purchasing process (Delafrooz et al., 2014) [20]. There are four (4) types of buying behaviour such as 
complex buying behaviour, variety behaviour, buying behaviour to overcome stress and lastly normal buying behaviour (Kotler, \&Armstrong, 2010) [21]. According to Daido (2004) [22], environmental changes can change the mind set and influences peoples' behaviour. Social media may affect consumers' buying behaviour towards green products. Additionally, Business Wire (2009) [23], in a survey for Adology Research found that social media or social networking such as Facebook, Twitter, LinkedIn,

YouTube, Flickr and others social media have significant impact on consumers purchasing behaviour.

\subsection{Green Marketing Practices}

\subsubsection{Concept and Definition of Green Marketing Practices}

Businesses and consumer of today are more concern to opt green products and services (Makhdoomi \& Nazir, 2016) [24], there were $93 \%$ of consumers who have involved to sustain environment (Hartman Group, 2007) [25] meanwhile, $37 \%$ of them consumers felt concerned about the environment (California Green Solution, 2007) [26]. Green marketing is how the business satisfy their customer needs and wants without giving harm to the environment due to scarcity of resources, (McTaggart et al., 1992) [27]. Business to adopt few marketing strategies to develop ecologically safer products, biodegradable, recyclable and good pollutions control to be competitive in the market (Czinkota and Ronkainen, 1992 [28]; Richards, 1994 [29]; Kotler and Armstrong, 1995 [30]). Tourism development activities are also involved with environmental improvement (Bolfa, T. E., 2019) [31]. Eco-labelling, eco-brand and environmental advertisement are the tools used in green marketing to increase the number of awareness from the society. As for, Malaysia, there were ten (10) hotels out of 86 hotels received winners of ASEAN Green Hotel awards in 2014 as shown in Table 2.1 (Malay Mail Online, 2014) [32]. Bui, (2005) [33], says that understanding, behaviour and values influence consumers' behaviour to purchase green products. Followed by Follows \& Jobber (2000) [34] agreed that there is a relationship between values, attitude and intention and purchasing behaviour of eco-friendly and non- eco-friendly products. Meanwhile, Laroche et al., (2001) [35], found that consumers are willing pay extra for green product depending on their demographic, behavior and psychology factors in North America.

Table 2.1

Winners of ASEAN Green Hotels in 2014

\begin{tabular}{|l|l|}
\hline Location & Hotel's Name \\
\hline Sabah & $\begin{array}{l}\text { Shangri-La Tanjung Aru } \\
\text { Resort and Spa Kota } \\
\text { Kinabalu } \\
\text { Nexus resort Karambunai } \\
\text { Shangri-La Rasa Ria } \\
\text { Resort Tuaran }\end{array}$ \\
\hline Sarawak & $\begin{array}{l}\text { Riverside Majestic Hotel } \\
\text { Kuching } \\
\text { Miri Marriot Resort and } \\
\text { Spa } \\
\text { Kuala Lumpur }\end{array}$ \\
$\begin{array}{l}\text { Mandarin Oriental } \\
\text { Shangri-La Hotel } \\
\text { Renaissance Hotel }\end{array}$ \\
\hline Kedah & The Andaman Langkawi \\
Penang & $\begin{array}{l}\text { Shangri-La Rasa Sayang } \\
\text { Resort and Spa }\end{array}$ \\
\hline
\end{tabular}

(Malay Mail Online, 2014)

\subsection{Shariah Compliance}

\subsubsection{Concept and Definition of Shariah Compliance}

Shariah compliance are products or services that follow the Islamic principles and concept (Samori \& Sabtu, 2014) [36], not limiting to foods and drinks, but also the operations and all the activities. Muslims purchasing habits are relatively relates to Halal image (Suki\& Salleh, 2016) [37] and Yunus et al., (2014) [38] added that most of the Muslim consumers seek for a product with halal logo as well as halal certification. Agreed by Azam, (2016) [39] saying that religious beliefs can be the factor of Muslim consumers' awareness in purchasing products or services. Malaysian Muslims purchase their foods and beverages by referring to the Halal logo from Islamic Development Department of Malaysia or JAKIM. Despite all this Kasim (2004) [40] founds that most of the Malaysian tourists do not put green hotel as their list of hotels to stay in. The main factor for a Muslim consumer is halal awareness and religious beliefs which help their decision-making process to purchase products or services. There is rapid awareness related with religious beliefs for Muslims 
consumer that makes them choose Shariah compliant products and services according to their religious beliefs and knowledge. (Henderson, 2003) [41]. Hadith has clearly said about awareness and proper consideration towards lawful and unlawful things. As a good Muslims, they will follow their religious beliefs wherever they are travelling to with a higher level of awareness regarding Shariah compliant attributes as halal foods, beverages and services. It will be a guideline for a traveller to travel according to their own religion and ethnicity. A tourist with less stressed has more attitude to a compliance behaviour (Antonio, P. et al, 2018) [42].

\subsection{Customer's Environmental Awareness}

\subsubsection{Concept and Definition of Customer's Environmental Awareness}

Dunlap and Jones (2002) [43] defined environmental awareness as people who are aware of the environmental problems and attempts to solve it. Arcury, (1990) [44] says positive attitudes happened when the knowledge regarding environmental issues increases, Lroche et al., (2001) [45] added that individual's attitude and behavior towards the environment relates with their knowledge about environment. A good knowledge about environmental issues makes individuals to be more responsible and concern towards the environment (Schahn\& Holzer, 1990) [46]. In addition, individuals will make green choices when they are concerned and aware about environmental (Van Bigelen et al., 2009) [47]. Besides that, society including businesses, companies and organizations had realized environmental issues such as pollutions, climate change, acid rain and waste disposal in the past 30 years ago (Papadopoulos et al., 2010) [48]. Mintel, (2006) [49] agreed that green behaviour from the customers who have intention to recycle and reuse, aware about pollution and willing to pay extra for green products to save the environment and support the efforts from organizations in increasing green behaviour.

\subsection{Customer's Satisfaction}

\subsubsection{Concept and Definition of Customer's Satisfaction}

Customer satisfy with a product base on the quality and the performance of the products and services which also influences their future purchase and loyalty (Makhdoomi\& Nazir, 2016) [50]. Example, customer repurchases the product and service in future when they are satisfied with it (Zeithml et al., 1996) [51]. On the other hand, Reynolds and Arnold, (2000) [52], defined satisfaction as when a customer recommends the products and services to others also known as word-of-mouth. Meanwhile, McCarthy \& Perrault, (2002) [53], added that customer feels satisfied when they receive products and services according to their expectations and worth the cost. Fourner and Mick (1999) [54] concluded that the concept of satisfaction holds well only when the expectation is positive. To obtain customer's high consumer's loyalty to sustain satisfaction is to deliver high customer value and a promised result from customers experience, (Sulaiman, Y., Masri, M., 2017) [55]. The key to generating high consumer's loyalty is delivering high consumer value. Moreover, in delivering profitable value, a company must develop a competitively superior value preferences won't change easily towards the product. The brand must represent a promise about the total resulting experiences that consumers can get by using the products.

\section{Methodology \\ 3.1 Description of Methodology}

This chapter discuss the methodology used to investigate the relationship between green marketing practices, Shariah compliance, customer's environmental awareness and customer's satisfaction with Muslim customer purchasing behaviour in hotel industry. It presents the research framework, hypothesis development and research design. After that, it is followed by the explanation on target population and sampling, sampling technique and questionnaire design used in this research. Finally, it will be discussed about data collection and how it will be analysed. 


\subsection{Research Framework}

Figure 1 below framed the research framework of this study based on the discussion of variables in the literature review section.

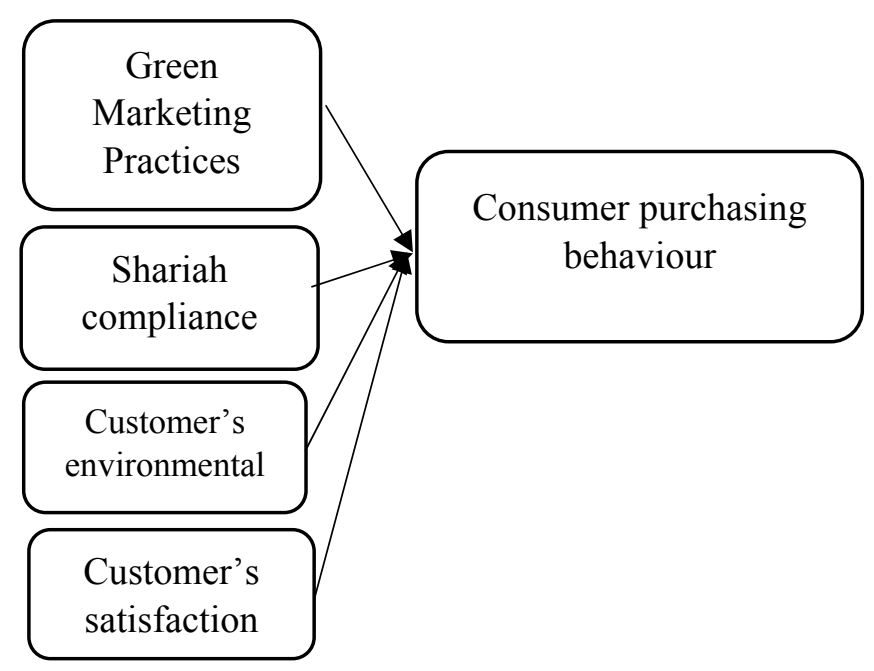

Figure 1: Research Framework

\subsection{Description of Methodology}

A quantitative approach was utilized for this research by distributing online questionnaires to local Muslim communities in Kedah using 'Likert scale'. The sampling frame of this research is Muslim local community in Kedah. Sample contains 403 respondents of Muslim local communities in Kedah, Malaysia. The measurements of variables (green marketing practices, shariah compliance, customer's environmental awareness, customer's satisfaction and consumer purchasing behaviour) are adapted from past instruments. Analysis methods used to measure the variables are Statistical Package for Social Science (SPSS version 25.0), reliability test and descriptive analysis.

\subsection{Data Collection Method}

Data was collected from two (2) sources which are primary data and secondary data. Primer data was collected through structured online questionnaires whereby 403 sets of questionnaires were distributed through online platform to local Muslim communities in Kedah. The online survey was posted through Whatsapp application and Facebook page. Secondary data used in this research are from external sources. Meanwhile, the secondary data used is to support the statement of this research are from internet journal, articles, websites and online publishing.

\subsection{Measurement}

All measurements scales for variables are obtained from existing developed scales. These variables are measured using 5-point Likert Scale from 1-Strongly Disagree to 5Strongly Agree.

\section{Findings and Conclusion}

\subsection{Reliability Test}

Table 4.1: Reliability test of the construct ( $\mathrm{n}=$ 30)

\begin{tabular}{l|ll}
\multicolumn{1}{c|}{ Variable } & $\begin{array}{l}\text { No of } \\
\text { item }\end{array}$ & $\begin{array}{l}\text { Cronbach's } \\
\text { Alpha } \\
\text { N=30 }\end{array}$ \\
\hline $\begin{array}{l}\text { Consumer } \\
\text { Purchasing Behavior }\end{array}$ & 4 & 0.720 \\
$\begin{array}{l}\text { Green Marketing } \\
\text { Shariah Compliance }\end{array}$ & 5 & 0.768 \\
$\begin{array}{l}\text { Customer's } \\
\text { Environmental } \\
\text { Awareness }\end{array}$ & 5 & 0.734 \\
$\begin{array}{l}\text { Customer's } \\
\text { Satisfaction }\end{array}$ & 5 & 0.795 \\
\hline
\end{tabular}

The measurement items for job green marketing practices, Syariah Compliance, Customer's environmental awareness and customer's satisfaction maintains an acceptable level Cronbach's Alpha value greater than 0.7 as shown in Table 4.1. The reliability result shows Cronbach's Alpha value greater than 0.7 for consumer purchasing behaviour, green marketing, Shariah compliance, customer's environmental awareness and customer's satisfaction as $0.720, \quad 0.768, \quad 0.734, \quad 0.795$ and 0.759 respectively. Therefore, based on the findings it is clear that all these four factors are significant. Hence, the value of measurement 
for both dependent and independent variables were excellent as the value were more than 0.7 .

\subsection{Results of Pearson Correlation}

\section{Analysis}

Table 4.2: Result of the Pearson Correlation Analysis between Dependent Variable and Independent Variables

\begin{tabular}{|c|c|c|c|c|}
\hline & $\begin{array}{l}\text { Consumer } \\
\text { purchasing } \\
\text { behavior }\end{array}$ & $\begin{array}{c}\text { Green } \\
\text { marketing }\end{array}$ & $\begin{array}{l}\text { Shariah } \\
\text { compliance }\end{array}$ & $\begin{array}{c}\text { Environmental } \\
\text { Awareness }\end{array}$ \\
\hline \multirow{3}{*}{$\begin{array}{l}\text { Consumer } \\
\text { purchasing } \\
\text { behavior }\end{array}$} & 1 & $.518^{* *}$ & $.334^{* 4}$ & $.380^{* *}$ \\
\hline & & .000 & .000 & .000 \\
\hline & 403 & 403 & 403 & 403 \\
\hline \multirow[t]{3}{*}{ Green marketing } & $.518^{4 *}$ & 1 & $.439^{4 *}$ & $.504^{* *}$ \\
\hline & .000 & & .000 & .000 \\
\hline & 403 & 403 & 403 & 403 \\
\hline \multirow{3}{*}{$\begin{array}{l}\text { Shariah } \\
\text { compliance }\end{array}$} & $.334^{* *}$ & $.439^{* *}$ & 1 & $.335^{* *}$ \\
\hline & .000 & .000 & & .000 \\
\hline & 403 & 403 & 403 & 403 \\
\hline \multirow{3}{*}{$\begin{array}{l}\text { Environmental } \\
\text { Awareness }\end{array}$} & $.380^{4 *}$ & $.504^{* *}$ & $.335^{* 4}$ & 1 \\
\hline & .000 & .000 & .000 & \\
\hline & 403 & 403 & 403 & 403 \\
\hline \multirow{3}{*}{$\begin{array}{l}\text { Customer } \\
\text { satisfaction }\end{array}$} & $.312^{* 4}$ & $.492^{* *}$ & $.329^{* *}$ & $.296^{* *}$ \\
\hline & .000 & .000 & .000 & .000 \\
\hline & 403 & 403 & 403 & 403 \\
\hline
\end{tabular}

Table 4.2 summarizes the results of correlation between consumer purchasing behaviour and implementation of green marketing and Shariah compliance in hotel industry of the 403 respondents participated in this study. Outcome shows that green marketing having strong significant relationship with consumer purchasing behaviour with correlation coefficient value of 0.518 . This indicates that most of the respondents are aware about green marketing $(r=0.518, p<0.001)$. As for Shariah compliance and consumer purchasing behaviour, it is moderately connected to consumer purchasing behaviour with correlation coefficient value of 0.334 . Therefore, it can be concluded that some of the respondents knows about Shariah compliance $(r=0.334, \quad p<0.001$. With regard to the customer's environmental awareness, result shows that it is having a positively medium significant relationship with consumer purchasing behaviour with correlation coefficient value of 0.380 . So, it can be concluded that some of the respondents have environmental awareness $(\mathrm{r}=0.380, \mathrm{p}<0.001)$. Finally, customer satisfaction has a positive medium significant relationship with consumer purchasing behaviour with correlation coefficient value of 0.312 indicating that some of the respondents are satisfied with the implementation of green marketing and
Shariah compliance in hotel industry $(\mathrm{r}=0.312$, $\mathrm{p}<0.001$ ).

\subsection{Multiple Regression Analysis}

Table 4.3: Regression Analysis

\begin{tabular}{|c|c|c|c|c|c|c|}
\hline \multirow{2}{*}{\multicolumn{2}{|c|}{ Model }} & \multicolumn{2}{|c|}{$\begin{array}{l}\text { Unstandardized } \\
\text { Coefficients }\end{array}$} & \multirow{3}{*}{$\begin{array}{c}\text { Standardized } \\
\text { Coefficients } \\
\text { Beta }\end{array}$} & \multirow{3}{*}{$\begin{array}{c}\mathbf{t} \\
\\
\\
4.449\end{array}$} & \multirow{3}{*}{$\begin{array}{l}\text { Sig. } \\
.000\end{array}$} \\
\hline & & \multirow{2}{*}{$\begin{array}{l}\text { B } \\
5.774 \\
\end{array}$} & \multirow{2}{*}{$\begin{array}{c}\text { Std. } \\
\text { Error } \\
1.298 \\
\end{array}$} & & & \\
\hline 1 & (Constant) & & & & & \\
\hline & Green Marketing & .395 & .058 & .377 & 6.817 & .000 \\
\hline & Shariah Compliance & .120 & .054 & .105 & 2.201 & .028 \\
\hline & $\begin{array}{l}\text { Customer's } \\
\text { Environmental Awareness }\end{array}$ & .145 & .051 & .140 & 2.842 & .005 \\
\hline & Customer's Satisfaction & .044 & .042 & .051 & 1.047 & .296 \\
\hline
\end{tabular}

The result of regression analysis Table 4 indicated that all independent variable had positive beta coefficient value as green marketing, Syariah compliance, customer's environmental awareness and customer's satisfaction have $0.377,0.105,0.140$ and 0.51 respectively. This is supported by green marketing $(\mathrm{p}=0.000)$, Syariah compliance $(p=0.028)$, customer's environmental awareness $\quad(p=0.005)$ and customer's satisfaction $(\mathrm{p}=0.296)$. Based on the findings, it is clear that all these four factors are significant with the $\mathrm{P}$ value of $\mathrm{P}$ value is smaller than $0.05(p<0.05)$ to consumer purchasing behaviour except for customer's environmental awareness. The findings indicated green marketing, Syariah compliance, customer's environmental awareness and customer's satisfaction have significant relationship with consumer purchasing behaviour.

Therefore, all of the hypothesis are accepted as in Table 4.4

Table 4.4: Hypothesis testing result

\begin{tabular}{l|l} 
Hypotheses & Results \\
\hline H1: Green marketing has & Accepted \\
significant relationship with & \\
consumer purchasing behavior & \\
in hotel industry. & \\
H2: Shariah compliance has & Accepted \\
significant relationship with & \\
consumer purchasing behavior & \\
in hotel industry. \\
H3: Customer's environmental & Accepted \\
awareness has significant &
\end{tabular}


relationship with consumer purchasing behavior in hotel industry.

H4: Customer's satisfaction has significant relationship with consumer purchasing behavior in hotel industry.

Consumer purchasing behaviour is related to green marketing. Therefore, the hotel industry may focus on green marketing to attract consumers for their continuous improvement. Consumer purchasing behaviour is also influenced by Shariah compliance, hence Hotel Industry should comply with Shariah according to Quran to sustain their business growth. On the other hand, it is found that consumer purchasing behaviour is less connected with customer's environmental awareness, anyhow, Hotel industry should be aware that the customer's environmental awareness is likely important in order to preserve the environment customer's religious beliefs. Apart from this, consumer purchasing behaviour is also having a medium relationship with customer's satisfaction. Even though it is in a medium level, Hoteliers must ensure that their service can meet their customer expectation to hold a strong customer base. Thus, the outcome of this study may be beneficial not only to the scholars, but also to governments and hotel industry from the perspective of green marketing, Shariah compliance, customer's environmental awareness and customer's satisfaction in the hotel industry as Malaysia is growing as Halal hub now.

Despite the importance of green marketing and Shariah compliance in hotel industry, empirical research for Shariah compliance is limited in hotel industry, so there are still some opportunities for researchers' to investigate the relationship of Shariah compliance and consumer purchasing behaviour in hotel industry for future studies. Since this study only focused in Kedah, future research may include all of the states in Malaysia or other country as different places may have different consumer purchasing behaviour. Other than that, future studies could adopt qualitative approach to have a better understanding of consumer purchasing behaviour based on depth of interview with them.

\section{Acknowledgement}

Yaty Sulaiman is a Senior Lecturer of Marketing, School of Business Management, College of Business, Universiti Utara Malaysia 06010 Sintok, Kedah, Malaysia. The author would like to thank The Ministry of Higher Education (MOHE) for granting this research under the Fundamental Research Grant Scheme (FRGS) and Research Innovation Management Centre (RIMC) Universiti Utara Malaysia. This article is under FRGS grant research, 2019/1 (S/O Code 14409).

\section{References}

[1] Punitha, S., Aziz, Y. A., \& Rahman, A. A. (2016). Consumers' Perceptions of Green Marketing in the Hotel Industry. Asian Social Science, 12(1), 1

[2] PEW Forum of Religion and Personal Life (2011) The Future of the Global Muslim Population: Projections for 2010-2030, Washington, DC.

[3] Omar, C.M.C., Islam, M.S. and Adaha, N.M.A. (2013) 'Perspectives on Islamic tourism and Shariah compliance in the hotel management in Malaysia', Paper presented at the Islamic Economics and Business

[4] Tourism Malaysia, (2016), Annual Report 2016: International Tourist Arrivals. Retrieved from https://www.tourism.gov.my/pdf/uploads /activities/Tourism_AR2016.pdf

[5] World Travel and Tourism Council, (2019). Malaysia: 2019 Annual Research Key Highlight. Retrieved from https://www.wttc.org/

[6] Forbes New York Business Council, (2018). Do Customers Really Care About Your Environmental Impact? Retrieved from

https://www.forbes.com/sites/forbesnycou ncil/2018/11/21/do-customers-really-careabout-your-environmentalimpact/\#45fba921240d

[7] Gitobu, J. K., \& Njoroge, J. M. (2014). Adoption of green marketing practices by hotels in Mombasa County, Kenya. Unpublished MBA Project: University of Nairobi

[8] Fernández-Alles, M. T., \& CuadradoMarqués, R. (2012). Hotel environmental impact management: A case study in Cádiz Province. In Soft Computing in 
Management and Business Economics (pp. 335-346). Springer, Berlin, Heidelberg

[9] Makhdoomi, U., \& Nazir, U. (2016). Consumers Purchase Behavior towards Green Products. Marketing in Emerging Economies, 15.

[10] Halal JAKIM Online www.halaljakim. gov.my, 2012

[11] Shaharuddin, N. A., Kassim, S., Yusof, A. M., Abu, N., \& Bakar, N. A. C. T. (2018). The Customer's Perception towards Shariah-Compliant Hotel in Malaysia

[12] Othman, R., Ibrahim, M., Hashim, S., Hakim, L., Din, A.M., Abdul Majid, N., Baharuddin, Z. M. (2014- 2018). Development of rating tools and audit systems for Shari'ah compliant hospitality services. Research Project of Niche Research Grant Ministry of Education Malaysia (NRGS 130010001), International Institute for Halal Research and Training (INHART), International Islamic University Malaysia (IIUM).

[13] Ahmat, N. C., Ridzuan, A. H. A., Din, N., Zainol, N., \& Razali, M. A. (2015). Syariah Compliant Hotel: The Concept and Practices. Journal of Tourism, Hospitality \& Culinary Arts, 7(2), 52-66.

[14] Azizah Musa, Suhaila Abdul Kadir, Mazne Ibrahim, Norzaliha Jusoh, Siti Nurzahira Che Tahrim, and Noormariana Mohd Din, (2017). Developing A Proper Framework Towards Shariah-Compliant Hotel In Malaysia: Identifying Opportunities And Challenges. Journal of Global Business and Social Entrepreneurship (GBSE), Vol. 1: no. 4 (2017) page 103-111.

[15] Idris, J., \& Abdul Wahab, N. (2015).The Competitive Advantages of ShariaCompliant Hotel Concept in Malaysia: SWOT Analysis. Retrieved from: http://www.kuis.edu.my/icomm/2nd/down load/IC\%20015.pd

[16] Samori, Z. \& Rahman, F.A. (2015). Establishing Shariah Compliant Hotels in Malaysia: Identifying Opportunities, Exploring Challenges. West East Journal of Social Sciences, 2(2), 95-108.

[17] Westeastinstitute.com (2018) Retrieved 2 March 2018, from https://www.westeastinstitute.com/wpcontent/uploads/2013/07/Zakiah-SamoriFull-Paper.pdf
[18] Sahida, W., Rahman, S. A., Awan, K., \& Man, Y. C. (2011). The implementation of shariah compliance concept hotel: De Palma hotel,Ampang, Malaysia, In International Conference on Humanities, Historical and Social Sciences, IACSIT Press, Singapore, IPEDR, 17, 138-142.

[19] Ahmad, M. S., Ariffin, A. A. M., \& Ahmad, A. (2008). Evaluating the services of Malaysian hotels from the leisure traveler 's perspectives. Jurnal Pengurusan, 27, 69-83.

[20] Delafrooz, N., Taleghani, M., \& Nouri, B. (2014). Effect of green marketing on consumer purchase behavior. QScience Connect, 5.

[21] Kotler P, Armstrong G. Principles of Marketing. 13th ed. Prentice Hall; 2010

[22] Daido, K. (2004). Risk-averse agents with peer pressure. Applied Economics Letters, 11, 383-386

[23] Business Wire - Spas and Salons Need to Get Social: Younger Demographics Influenced by Social Media. (2009, June). Retrieved April 04, 2013, from http://www.businesswire.com/news/home/ 20090630006054/en/SpasSalons-SocialYounger-Demographics-InfluencedSocial\#.U1jJ4CQZ7jo

[24] Makhdoomi, U., \& Nazir, U. (2016). Consumers Purchase Behavior towards Green Products. Marketing in Emerging Economies, 15.

[25] Hartmann Group (2007), The Hartman Report on Sustainability: Understanding the Consumer Perspective, Hartman Group, Bellevue, WA

[26] California Green Solutions (2007), Green Consumer Research Outlines the Challenge. Retrieved from http://www.californiagreensolutions.com/

[27] McTaggart, D.; Findlay, C.; Parkin, M. (1992). Economics. Addison-Wesley, Sydney

[28] Czinkota, M. R., \& Ronkainen, I. A. (1992). Global marketing 2000: A marketing survival guide. Marketing management, 1(1), 36-43.

[29] Richards, D. J. (1994). Environmentally conscious manufacturing. World class design to manufacture, 1(3), 15-22.

[30] Kotler P, Armstrong G. Principles of Marketing. 13th ed. Prentice Hall; 2010

[31] Bolfa Traian Eugen, Studies Regarding Tourism Development Perspectives in the 
Existing Economical and Environmental

Context WSEAS Transactions on Environment and Development, Volume 15, 2019, pp. 197-203

[32] Malay Mail Online. (2014, January 19). 10 hotels in Malaysia win Asean Green Hotel title. Retrived from http://www.themalaymailonline.com/trave 1/article/ten-hotels-in-malaysia-win-aseangreen-hotel-titl

[33] Bui, M. H. (2005, March). Environmental marketing: A model of consumer behavior. In Proceedings of the Annual Meeting of the Association of Collegiate Marketing Educators (Vol. 20, pp. 24-26). New Orleans.

[34] Follows, S. B., \& Jobber, D. (2000). Environmentally responsible purchase behaviour: a test of a consumer model. European journal of Marketing, 34(5/6), 723-746.

[35] Laroche, M., Bergeron, J., \& BarbaroForleo, G. (2001). Targeting consumers who are willing to pay more for environmentally friendly products. Journal of consumer marketing, 18(6), 503-520.

[36] Samori, Z., \& Sabtu, N. (2014). Developing halal standard for Malaysian hotel industry: An exploratory study. Procedia-Social and Behavioral Sciences, 121, 144-157

[37] Norazah Mohd Suki, and Abang Sulaiman Abang Salleh, (2016) Does Halal image strengthen consumer intention to patronize Halal stores?: Some insights from Malaysia. Journal of Islamic Marketing, 7 (1). pp. 120-132.

[38] Yunus, N. S. N. M., Rashid, W. E. W., Ariffin, N. M., \& Rashid, N. M. (2014). Muslim's purchase intention towards nonMuslim's Halal packaged food manufacturer. Procedia-Social and Behavioral Sciences, 130, 145-154.

[39] Azam, A. (2016). An empirical study on non-Muslim's packaged halal food manufacturers: Saudi Arabian consumers' purchase intention. Journal of Islamic Marketing, 7(4), 441-460.

[40] Kasim, A. (2004). Socio-environmentally responsible hotel business: Do tourists to Penang Island, Malaysia care?. Journal of Hospitality \& Leisure Marketing, 11(4), 528.

[41] Henderson, J. C. (2003). Managing tourism and Islam in peninsular
Malaysia. Tourism management, 24(4), 447-456.

[42] Antonio Pratelli, Marino Lupi, Carmela Iannelli, Andrea Lorenzini, Crossing at a Red Light: Behavior of Tourists and Commuters WSEAS Transactions on Environment and Development, Volume 14, 2018, pp. 263-269

[43] Dunlap, R. E. \& Jones, R. E. (2002). Environmental concern: conceptual and measurement issues. In Handbook of Environmental Sociology, Westport, CN: Greenwood Press.

[44] Arcury, T. A. (1990). Environmental attitude and environmental knowledge. Human organization, 300-304.

[45] Laroche, M., Bergeron, J., \& BarbaroForleo, G. (2001). Targeting consumers who are willing to pay more for environmentally friendly products. Journal of consumer marketing, 18(6), 503-520.

[46] Schahn, J., \& Holzer, E. (1990). Studies of individual environmental concern: The role of knowledge, gender, and background variables. Environment and behavior, 22(6), 767-786.

[47] Van Birgelen, M., Semeijn, J., \& Keicher, M. (2009). Packaging and proenvironmental consumption behavior: Investigating purchase and disposal decisions for beverages. Environment and Behavior, 41(1), 125-146.

[48] Papadopoulos, Ioannis, Glykeria Karagouni, Marios Trigkas, and Evanthia Platogianni. "Green marketing: The case of Greece in certified and sustainably managed timber products." EuroMed Journal of Business 5, no. 2 (2010): 166190.

[49] Mintel (2006), “Green living”, US Marketing Research Report, London

[50] Makhdoomi, U., \& Nazir, U. (2016). Consumers Purchase Behavior towards Green Products. Marketing in Emerging Economies, 15.

[51] Zeithaml, V. A., Berry, L. L., \& Parasuraman, A. (1996). The behavioral consequences of service quality. Journal of marketing, 60(2), 31-46.

[52] Reynolds, K. E., \& Arnold, M. J. (2000). Customer loyalty to the salesperson and the store: examining relationship customers in an upscale retail context. Journal of personal selling \& sales management, 20(2), 89-98. 
[53] McCarthy, E. J., Shapiro, S. J., \& Perreault, W. D. (1979). Basic marketing (pp. 29-33). Irwin-Dorsey.

[55] Sulaiman, Y., Masri, M. (2017). The impact of marketing mix on consumer preference towards supplement product.
[54] Fournier, S., \& Mick, D. G. (1999). Rediscovering satisfaction. Journal of marketing, 63(4), 5-23.

Journal of Advanced Research in Social and Behavioural Sciences, 7(1), 33-41. 